\title{
Contrasts in density, size, and biomass of reef fishes between the northwestern and the main Hawaiian islands: the effects of fishing down apex predators
}

\author{
Alan M. Friedlander ${ }^{1, *}$, Edward E. DeMartini $^{2}$ \\ ${ }^{1}$ The Oceanic Institute, Makapuu Point/41-202 Kalanianaole Highway, Waimanalo, Hawaii 96795, USA \\ ${ }^{2}$ National Marine Fisheries Service, Southwest Fisheries Science Center, Honolulu Laboratory, 2570 Dole Street, Honolulu, \\ Hawaii 96822-2396, USA
}

\begin{abstract}
A comparison between the northwestern Hawaiian islands (NWHI), a large, remote, and lightly fished area, and the main Hawaiian islands (MHI), an urbanized, heavily fished area, revealed dramatic differences in the numerical density, size, and biomass of the shallow reef fish assemblages. Grand mean fish standing stock in the NWHI was more than $260 \%$ greater than in the MHI. The most striking difference was the abundance and size of large apex predators (primarily sharks and jacks) in the NWHI compared to the MHI. More than $54 \%$ of the total fish biomass in the NWHI consisted of apex predators, whereas this trophic level accounted for less than $3 \%$ of the fish biomass in the MHI. In contrast, fish biomass in the MHI was dominated by herbivores (55\%) and small-bodied lower-level carnivores (42\%). Most of the dominant species by weight in the NWHI were either rare or absent in the MHI and the target species that were present, regardless of trophic level, were nearly always larger in the NWHI. These differences represent both near-extirpation of apex predators and heavy exploitation of lower trophic levels in the MHI compared to the largely unfished NWHI. The reefs in the NWHI are among the few remaining large-scale, intact, predator-dominated reef ecosystems left in the world and offer an opportunity to understand how unaltered ecosystems are structured, how they function, and how they can most effectively be preserved. The differences in fish assemblage structure in this study are evidence of the high level of exploitation in the MHI and the pressing need for ecosystem-level management of reef systems in the MHI as well as the NWHI.
\end{abstract}

KEY WORDS: Apex predators · Overfishing $\cdot$ Hawaiian archipelago $\cdot$ Fish assemblage structure

\section{INTRODUCTION}

With coral reefs around the world in decline, it is extremely rare to be able to examine a coral reef ecosystem that is relatively free of human influence. Although pollution, coastal development, and global climate change all impact coral reefs, fisheries exert the most direct and pervasive influence on these and other marine ecosystems (Jennings \& Kaiser 1998, Jackson et al. 2001). Large marine vertebrates such as whales, manatees, turtles, groupers, and sharks have

*E-mail: afriedlander@oceanicinstitute.org been systematically removed from the ocean by humans over the past $500 \mathrm{yr}$ and are now effectively absent from most coastal ecosystems worldwide (NRC 1995, Jackson et al. 2001, Pitcher 2001). Populations of important species in many marine ecosystems are now so low that they cannot exert their former ecological role (Dayton 1998), and the indirect effects of the reductions of these species are unknown because no baseline data exist for comparison (Dayton et al. 1998). Modern studies of marine ecosystems began long after enormous changes in these systems had occurred (Jackson 1997, Jackson et al. 2001), and the 'shifting baseline syndrome' (Pauly 1995, Sheppard 1995) makes it difficult to determine what constitutes a nat- 
ural ecosystem and how to manage these ecosystems accordingly.

Fisheries on coral reefs tend to focus first on the larger more desirable species and progressively shift towards smaller less desirable ones as time goes on and resources decline (Koslow et al. 1988, Jennings \& Polunin 1996, 1997, Russ \& Alcala 1996). Fisheries remove large long-lived or slow-growing fish that are frequently replaced by those with higher turnover rates (Pitcher 2001). Typically these larger species are apex predators that importantly structure the coral reef fish assemblage and influence ecosystem function. This removal of apex predators is analogous to the extirpation of large mammalian megafauna on land during the late Pleistocene following the initiation of organized hunting by humans (Martin 1984, Ward 1997).

Remote locations with limited fishing pressure are some of the few remaining examples of coral reefs without major anthropogenic influence. The northwestern Hawaiian islands (NWHI) provide a unique opportunity to assess how a natural coral reef ecosystem functions in the absence of ongoing major human intervention. This chain of small islands, atolls, submerged banks, and reefs stretches for more than $2000 \mathrm{~km}$ northwest of the high windward main Hawaiian islands (MHI; Fig. 1). From Nihoa and Necker (roughly 7 and 10 million yr old respectively) to Midway and Kure atolls ( 28 million yr old), the NWHI represent the older portion of the emergent archipelago (Juvik \& Juvik 1998). The majority of the islets and shoals remain uninhabited, although Midway, Kure, Laysan, and French Frigate Shoals have all been occupied for extended periods by various government agencies over portions of the last century.

Recreational and commercial fishing activities are restricted within the 10 fathom $(\sim 18 \mathrm{~m})$ isobath of most of these islands (20 fathoms around Necker Island) owing to their status as a National Wildlife Refuge managed by the US Fish and Wildlife Service (USFWS). The National Marine Fisheries Service (NMFS) has also designated 10 areas out from shore to 20 fathoms in the NWHI as critical habitat for the federally endangered Hawaiian monk seal. Commercial fishing in the NWHI within $100 \mathrm{~m}$ depth targets mostly bottomfish and lobster, each of which is managed separately by the NMFS through the actions of an advisory body, the Western Pacific Regional Fisheries Management Council. Both of these fisheries have limited entry, with fewer than 20 vessels allowed to operate in each fishery. Typically, only a small proportion of these vessels actively fish in any given year.

The federal waters of the NWHI received significant new protection in December 2000, when US President Clinton established the NWHI Coral Reef Ecosystem Reserve by Executive Order 13178 amended with Executive Order 13196 in January 2001. This large reserve area, extending 1200 nautical miles $(2200 \mathrm{~km})$ in length and 3 to 50 nautical miles ( 6 to $93 \mathrm{~km}$ ) from the shorelines, is to be managed by the Secretary of Commerce and will be designated as a National Marine Sanctuary. The Executive Order also established fifteen Reserve Preservation Areas within the reserve, in which extractive use is prohibited with limited exceptions.

In the mid-1970s, NMFS, USFWS, the University of Hawaii Sea Grant College Program, and the Hawaii Department of Fish and Game (since renamed Division of Aquatic Resources) began a 5 yr survey and assessment of the marine resources of the NWHI. Surveyors found the coral reef fish community in the NWHI to be strongly dominated by carnivores (mostly jacks, sharks, goatfishes, scorpionfishes, bigeyes, and squirrelfishes). Moreover, these as well as other prized

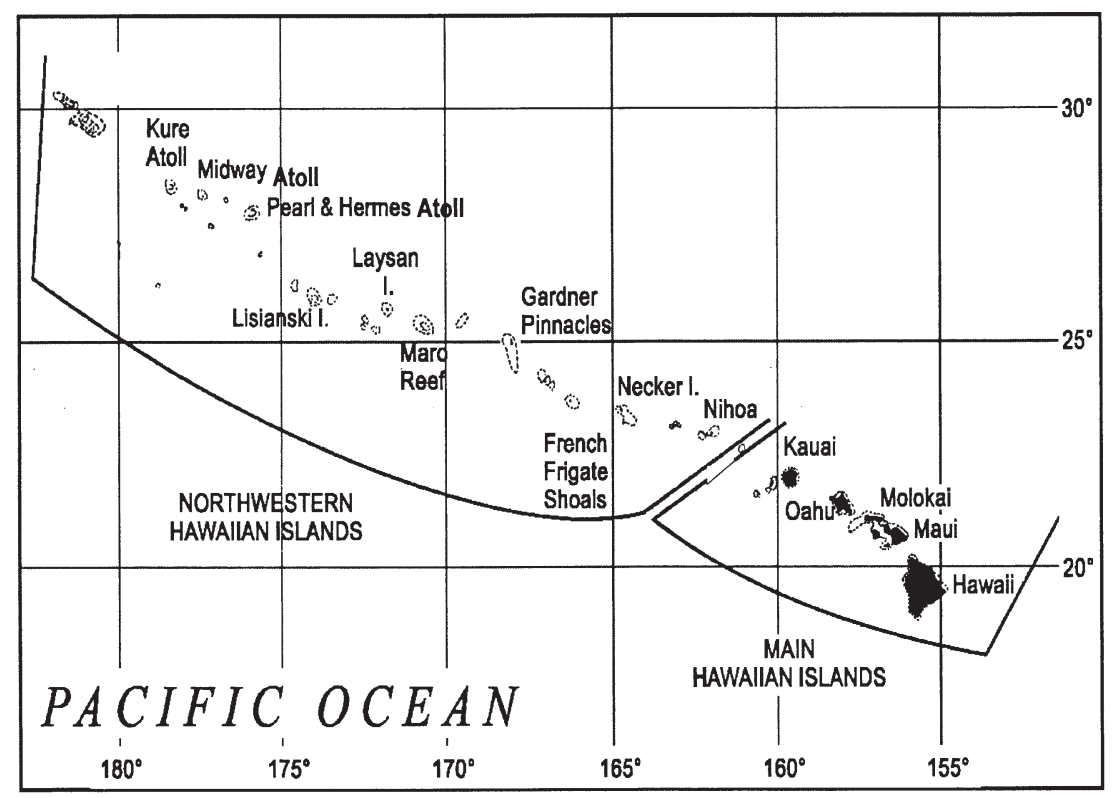

Fig. 1. Map of the Hawaiian Archipelago showing major islands, reefs, and atolls. The main Hawaiian islands extend from Hawaii to Niihau. The northwestern Hawaiian islands range from Nihoa to Hancock Bank 
resource species tended to be larger and more abundant in the NWHI compared to the populated areas of the state of Hawaii (Okamoto \& Kawamoto 1980, Hobson 1984, Parrish et al. 1985). More quantitative studies at French Frigate Shoals and Midway Atoll in the 1980s and 1990s document biomass estimates of nonapex carnivorous and herbivorous fishes on shallow reefs almost twice as high as those observed in the MHI, probably reflecting differences in fishing pressure (DeMartini et al. 1996).

In contrast to the NWHI, the MHI are heavily populated and highly urbanized. Reefs of the MHI once provided the majority of the protein for the Hawaiian people; nowadays consumptive uses of reef resources include commercial and recreational as well as subsistence activities. Coastal fisheries in the MHI are facing overexploitation and severe depletion. This decline in abundance, particularly around the more populated areas of the state, is likely the cumulative result of years of chronic overfishing (Shomura 1987, Gulko et al. 2000). Fishing pressure on nearshore resources in heavily populated areas of the MHI appears to exceed the capacity of these resources to renew themselves (Smith 1993) and fishery resources are more abundant in areas where fishing activities are limited (Lowe 1996). There are currently 3426 registered commercial fishermen in Hawaii (Hawaii Division of Aquatic Resources data) and the most recent survey of recreational fishing in Hawaii reported 230000 anglers who fished a total of 3.1 million days a year (USFWS 1998).

Factors contributing to the decline of inshore fisheries in the MHI include a growing human population in Hawaii, destruction or disturbance to habitat, introduction of new fishing techniques (inexpensive monofilament gill nets, scuba, spear guns, power boats, sonar fish finders), and loss of traditional conservation practices (Lowe 1996, Friedlander et al. in press). Intensive fishing pressure on highly prized and vulnerable species has raised concerns about the longterm sustainability of these stocks (Friedlander \& Parrish 1997, Friedlander \& Ziemann in press). Despite the opinion of many fishermen that overharvesting is one of the major reasons for the long-term decline in inshore marine resources, there is poor compliance with state fishing laws and regulations.

The purpose of this paper is to compare the fish standing stock, trophic dynamics, and assemblage structure of the large, isolated, generally inaccessible, and relatively unfished NWHI with the more intensely fished reefs of the densely populated MHI. Examination of a large-scale and lightly exploited ecosystem like the NWHI allows us to describe a system that may represent one of the last remaining natural baselines for coral reef ecosystems on earth.

\section{MATERIALS AND METHODS}

Fish sampling methodology. Abundance of fishes on hard substrate in the MHI was assessed using standard underwater visual belt transect survey methods (Brock 1954, 1982). Four $25 \times 5 \mathrm{~m}$ transects, separated by $5 \mathrm{~m}$ gaps, were conducted at each location. Total length (TL) of fish was estimated to the nearest centimeter. A diver swam each transect at a constant speed ( 15 min per transect), identifying to the lowest possible taxon all fishes visible within $2.5 \mathrm{~m}$ to either side of the centerline (125 $\mathrm{m}^{2}$ transect area). Transects were located along the centerline of previously established benthic survey grids. All fish surveys in the MHI were conducted between May 2000 and May 2001.

Belt transects in the NWHI were conducted by pairs of divers for safety and logistical reasons. A pair of divers swam three $25 \mathrm{~m}$ long transects, recording sizeclass specific (i.e. by TL) counts of fishes encountered within visually estimated but defined belt widths, either as one of the divers set the transect line or as the divers swam back along the line. Each diver obtained a density estimate of all fishes $>20 \mathrm{~cm}$ TL within a $25 \times$ $4 \mathrm{~m}\left(100 \mathrm{~m}^{2}\right)$ area on an initial 'swim-out' leg, followed by a density estimate of fishes $\leq 20 \mathrm{~cm}$ TL within a $25 \times$ $2 \mathrm{~m}\left(50 \mathrm{~m}^{2}\right)$ area on the subsequent 'swim back' leg, on each transect. Surveys in the NWHI were conducted from September to October 2000 as part of a 2-vessel multiagency assessment of the resources of the NWHI.

Length estimates of fish from visual censuses were converted to weight using the allometric lengthweight conversion: $W=a \mathrm{SL}^{b}$, where parameters $a$ and $b$ are constants, SL is standard length in $\mathrm{mm}$, and $W$ is weight in grams. Total length was converted to SL by using published and web-based conversion factors ${ }^{1}$. Length-weight fitting parameters were available for 150 species commonly observed on visual fish transects in Hawaii (Hawaii Cooperative Fishery Research Unit unpubl. data). This was supplemented by using information from other published and web-based sources $^{1}$. In the cases where length-weight information did not exist for a given species, the parameters from similar bodied congeners were used.

All stations in the NWHI were categorized a priori as occurring in either lagoonal or ocean facing habitats. Ocean facing stations included outer barrier habitat for atolls, all stations at the basaltic islands of Necker, Nihoa, and Gardner, and islands without protective perimeters (Lisianski/Neva Shoals, and Maro Reef). Only non-lagoonal stations were used in comparisons between the NWHI and MHI because of the absence of lagoon habitat at the latter island group. Stations in

\footnotetext{
${ }^{1}$ See www.fishbase.org
} 
Kaneohe Bay, the only true barrier reef system sampled in the MHI, have uniquely different benthic habitat and fish assemblage structure than all other stations in the MHI (Friedlander et al. unpubl.) and were therefore also excluded from the analysis.

Species were grouped into consumer guilds based on previously published diet and feeding habit information. Apex predators included only large piscivorous species that are known or likely to have an important influence on fish assemblage trophic dynamics. These included all sharks, large carangids, the endemic Hawaiian grouper Epinephelus quernus, barracuda Sphyraena barracuda, and grey snapper Aprion virescens. All non-apex predator carnivores were pooled as lower-level carnivores.

Statistical analysis. Detrended correspondence analysis (DCA) was used to identify clusters of similar stations in ordination space. A matrix of reefs (9 from the NWHI and 6 from the MHI) by fish species (grand mean biomass per reef) was created for use in this analysis. Values were ln-transformed with rare species downweighted. Those taxa that occurred at less than $20 \%$ of the number of stations at which the most common taxon occurred were downweighted. The amount that the species was downweighted was inversely related to its frequency of occurrence. This ordination technique results in an arrangement of species samples in low-dimensional space such that similar samples are in close proximity to one another (Gauch 1982). Habitat variables do not influence the ordination; rather, stations with similar assemblage structure cluster together (Greenfield \& Johnson 1990).
Transects within stations were not independent and mean values per station were used in all statistical analyses. The Mann-Whitney rank sum test was used to compare numerical and biomass densities between the NWHI and MHI groups. Grand mean weight (total fish) per station between island groupings was compared using an unpaired $t$-test, as was the comparison of grand mean weight of apex predators and herbivores. In both cases data were ln-transformed to conform to the assumptions of normality. Grand mean weight of lower-level carnivores was compared using the Mann-Whitney rank sum test.

The top 17 species by weight in the NWHI each accounted for more than $1 \%$ of the total biomass. Because the contribution of additional species was small, these species were not considered in specieslevel comparisons. A binomial test was conducted on the nominal (signed) differences in numerical abundance, biomass, and mean weight for the top 17 species between the NWHI and the MHI. Analogous comparisons of length-frequency distributions between important and/or representative species within each major consumer guild were made using 2-sample Kolmogorov-Smirnov tests (Siegel \& Castellan 1988).

\section{RESULTS}

\section{Fish assemblage structure}

Fish assemblage structure within the NWHI and MHI formed distinct clusters in ordination space (Fig. 2).

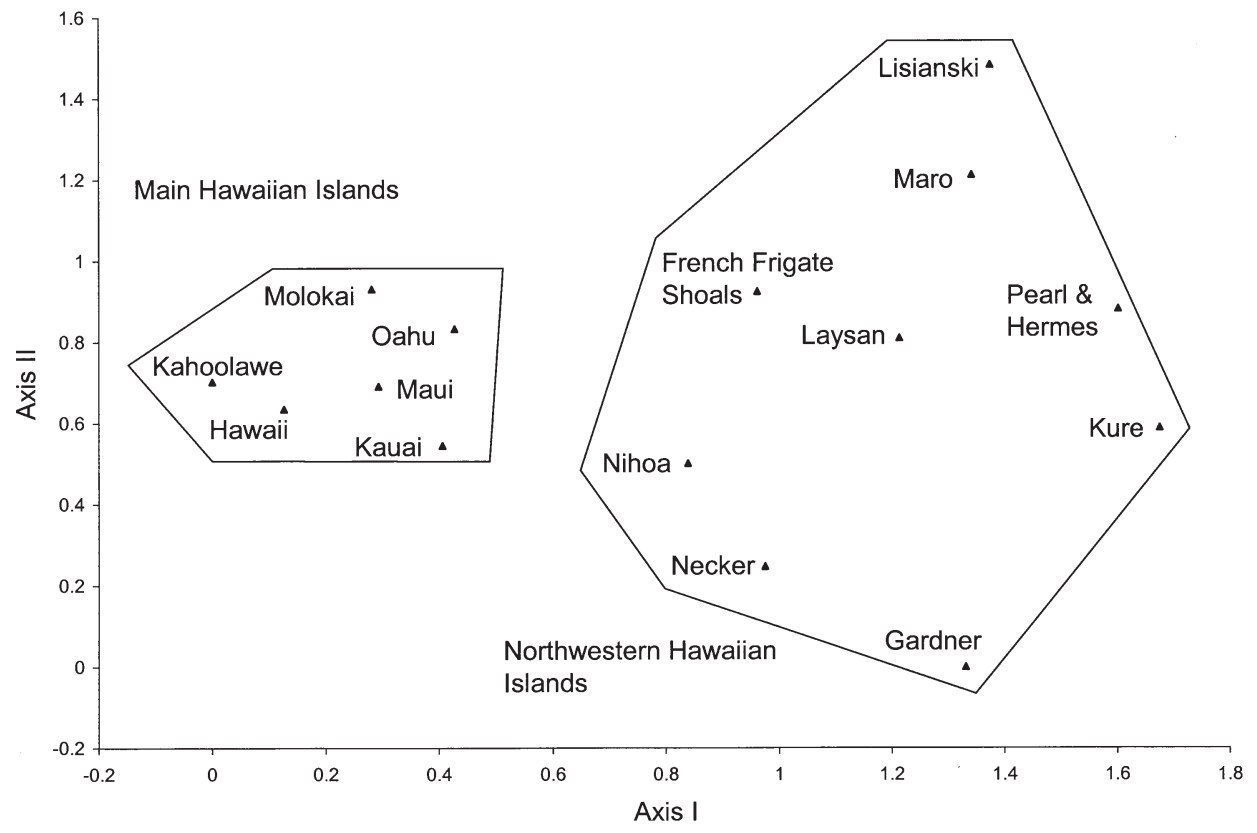

Fig. 2. Results of detrended correspondence analysis of fish assemblages in the main Hawaiian islands and northwestern Hawaiian islands. Input values were grand mean biomass of taxa at each reef. Values were ln-transformed for analysis, with rare species downweighted. Axis I: eigenvalue $=0.42$, percentage of total variance $=25.5$. Axis II: eigenvalue $=0.10$, percentage of total variance $=11.0$ 
Islands within the MHI cluster showed high concordance, while the diversity of reefs, atolls, and basaltic islands in the NWHI exhibited higher degrees of variation in fish assemblage structure. The first DCA axis showed a general shift in assemblage structure along a latitudinal gradient moving to the right from the MHI to the NWHI. The basalt islands of Necker, Nihoa, and Gardner Pinnacles are closest to one another in ordination space along the lower end of Axis II. The 2 complete atolls of Kure and Pearl and Hermes have higher concordance with one another than with other reefs, as do Lisianski/Neva Shoals and Maro, 2 reticulated reefs with lagoons lacking protective perimeter reefs.

\section{Density, size, and standing stock}

Grand mean biomass density in the NWHI was $2.44 \mathrm{t}$ $\mathrm{ha}^{-1}(\mathrm{SD}=2.99)$ compared to $0.68 \mathrm{t} \mathrm{ha}^{-1}(\mathrm{SD}=0.59)$ for the $\mathrm{MHI}(T=2380, \mathrm{p}<0.001)$. When no-take marine protected areas are excluded from the MHI calculation, mean biomass drops to $0.59 \mathrm{t} \mathrm{ha}^{-1}(\mathrm{SD}=0.55)$. Overall grand mean biomass was highest at Pearl and Hermes Atoll in the NWHI (mean $=4.64 \mathrm{t} \mathrm{ha}^{-1}, \mathrm{SD}=$ 5.37 ) and lowest on Kauai in the MHI (mean $=0.41 \mathrm{t}$ $\mathrm{ha}^{-1}, \mathrm{SD}=0.39$ ) (Fig. 3). Hanauma Bay, the first notake marine protected area established in Hawaii in
1967, had the highest biomass on the island of Oahu, where over $70 \%$ of the state's population resides. If this location is excluded, biomass on Oahu declines from 0.64 to $0.24 \mathrm{t} \mathrm{ha}^{-1}$, which represents the lowest biomass observed among all locations. Kahoolawe Island is currently uninhabited and is managed by the Kahoolawe Island Reserve Commission with current administrative rules limiting fishing for cultural, spiritual, and subsistence purposes. This island had the highest biomass in the MHI (mean $=1.28 \mathrm{t} \mathrm{ha}^{-1}, \mathrm{SD}=0.09$ ) and was similar to the biomass observed at Kure Atoll in the NWHI (mean $1.2 \mathrm{t} \mathrm{ha}^{-1}, \mathrm{SD}=0.89$ ).

There was a significant difference (Mann-Whitney $T=3188, \mathrm{p}<0.001$ ) in the grand mean density (number of individual fish per ha) between the NWHI (mean = $13240, \mathrm{SD}=7140$ ) and the MHI (mean $=9200, \mathrm{SD}=$ $4,350)$. Additionally, grand mean weight per individual was significantly greater $(T=6.78, \mathrm{p}<0.001)$ in the NWHI (mean $=215 \mathrm{~g}$, SD $=320$ ) compared to the MHI $($ mean $=66 \mathrm{~g}, \mathrm{SD}=41)$.

\section{Consumer guilds}

More than $54 \%$ of the total fish biomass in the NWHI consisted of apex predators, primarily sharks and jacks (Table 1). They were followed in importance in bio-

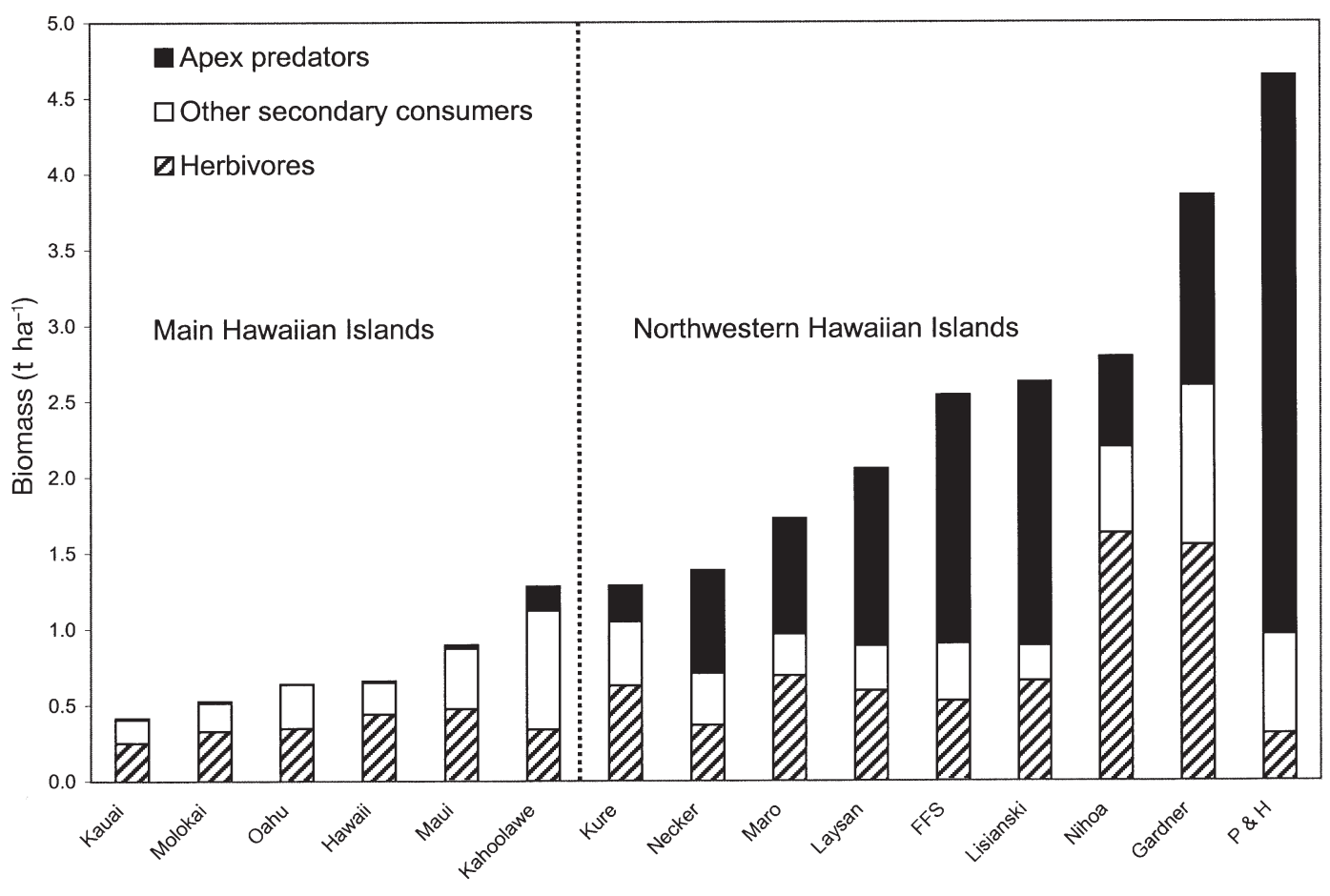

Fig. 3. Ranked (from left to right, lowest to highest) total grand mean biomass and grand mean biomass by trophic level for all reefs surveyed in the main Hawaiian islands and northwestern Hawaiian islands. FFS = French Frigate Shoals; P \& H = Pearl and Hermes 
Table 1. Comparison of biomass density $\left(\mathrm{t} \mathrm{ha}^{-1}\right)$, numerical density (number ha $\mathrm{h}^{-1}$ ), mean weight of individuals $(\mathrm{g}$ ) between stations in the northwestern Hawaiian islands (NWHI) and the main Hawaiian islands (MHI). Values are grand means with 1 SD in parentheses. $\mathrm{n}=106$ for the NWHI and $\mathrm{n}=52$ for the MHI. Test statistics: $T$ for results of Mann-Whitney Rank Sum Test and $t$ for results of unpaired $t$-test

\begin{tabular}{|c|c|c|c|c|c|}
\hline & NWHI & MHI & $\begin{array}{c}\text { Test } \\
\text { statistic }\end{array}$ & $\mathrm{p}$ & $\begin{array}{c}\text { Percent } \\
\text { difference }\end{array}$ \\
\hline \multicolumn{6}{|l|}{ Biomass } \\
\hline Apex predators & $1.31(2.71)$ & $0.02(0.08)$ & $T=2201$ & $<0.001$ & 7012 \\
\hline Herbivores & $0.68(1.25)$ & $0.37(0.34)$ & $T=3497$ & 0.019 & 83 \\
\hline $\begin{array}{c}\text { Lower-level } \\
\text { carnivores }\end{array}$ & $0.44(0.43)$ & $0.28(0.33)$ & $T=3256$ & 0.001 & 55 \\
\hline \multicolumn{6}{|l|}{ Number } \\
\hline Apex predators & $132(314)$ & $12(24)$ & $T=2476$ & $<0.001$ & 984 \\
\hline Herbivores & $4633(5210)$ & $3979(2844)$ & $T=4221$ & 0.749 & 16 \\
\hline $\begin{array}{l}\text { Lower-level } \\
\text { carnivores }\end{array}$ & $8477(5594)$ & $5212(2358)$ & $T=3183$ & $<0.001$ & 63 \\
\hline \multicolumn{6}{|l|}{ Mean weight } \\
\hline Apex predators & 10466 (9209) & 1561 (3926) & $t=10.431$ & $<0.001$ & 570 \\
\hline $\begin{array}{l}\text { Herbivores } \\
\text { Lower-level }\end{array}$ & $170(158)$ & $86(64)$ & $t=3.672$ & $<0.001$ & 97 \\
\hline carnivores & 63 (101) & $54(53)$ & $T=3951$ & 0.499 & 17 \\
\hline
\end{tabular}

The greatest proportion of apex predators was found at Pearl and Hermes Atoll (79\%) followed by Lisianski/Neva Shoals $(66 \%)$, both in the NWHI (Fig. 3). Kahoolawe, the only uninhabited island in the MHI, had the highest proportion of apex predators observed in the MHI (12\%) followed distantly by Maui $(2.4 \%)$. The densely populated island of Oahu had the lowest proportion of apex predators overall $(0.2 \%)$.

Although apex predators accounted for only $1 \%$ of the grand mean numerical density in the NWHI, their numerical abundance in the MHI was an order of magnitude lower $(0.1 \%)$. For all comparisons, density was higher in the NWHI compared to the MHI

mass by herbivores (28\%), mostly parrotfishes and surgeonfishes, and lower-level carnivores which comprised an assortment of small-bodied species (18\%). In contrast to the NWHI, less than $3 \%$ of the biomass in the MHI consisted of apex predators. Herbivores accounted for $55 \%$ of the MHI fish biomass with lowerlevel carnivores accounting for the remaining $42 \%$.

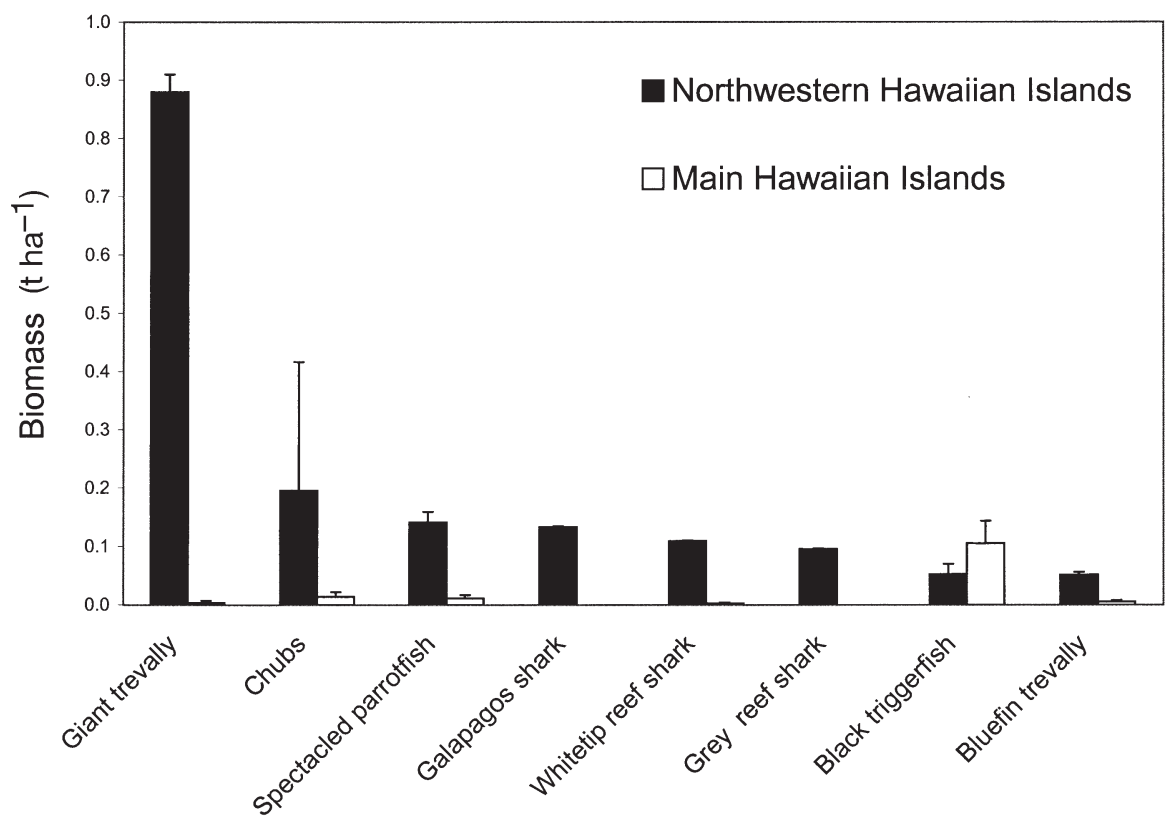

Fig. 4. Grand mean biomass (+SE) of the top 8 taxa by weight in the northwestern Hawaiian islands and corresponding values for these taxa in the main Hawaiian Islands and was significantly greater in all cases except for the numerical abundance of herbivores (Table 1). Mean weight of apex predators in the NWHI was $570 \%$ greater than in the MHI, while herbivores were $97 \%$ heavier in the NWHI. There was no significant difference in the mean weight of lower-level carnivores between the NWHI and MHI, owing largely to the black triggerfish Melichthys niger, a non-targeted species that accounted for nearly $37 \%$ of the total biomass of this trophic level in the MHI (see species results below).

\section{Species comparisons}

Most of the dominant species by weight in the NWHI were either rare or absent in the MHI (Fig. 4). For the top 17 species by weight, the number of positive nominal (signed) differences was significantly greater in the NWHI compared to the MHI for numerical abundance (16/17× greater, p < 0.001), biomass $(16 / 17 \times$ greater, $p<$ $0.001)$, and mean weight per individual $(15-17 \times$ greater, $\mathrm{p}<$ 0.001; Table 2). 
Table 2. Biomass densities ( $\mathrm{th}^{-1}$ ) for the top 17 species (each comprising $>1 \%$ of total) in the northwestern Hawaiian islands (NWHI) and corresponding values for these species in the main Hawaiian islands (MHI). Values are means per station with 1 SD in parentheses. no: not observed; nd: not determined

\begin{tabular}{|c|c|c|c|c|c|}
\hline $\begin{array}{l}\text { Taxon/ } \\
\text { common name }\end{array}$ & NWHI & MHI & $\begin{array}{l}\text { MHI } \\
\text { rank }\end{array}$ & $\begin{array}{c}\text { Percent } \\
\text { difference }\end{array}$ & $\begin{array}{l}\text { Consumer } \\
\text { guild }\end{array}$ \\
\hline $\begin{array}{l}\text { Caranx ignobilis } \\
\text { giant trevally }\end{array}$ & $0.88(0.31)$ & $<0.01(0.03)$ & 139 & +24571 & Apex predator \\
\hline $\begin{array}{l}\text { Kyphosus species } \\
\text { chubs }\end{array}$ & $0.20(2.27)$ & $0.01(0.06)$ & 13 & +1322 & Herbivore \\
\hline $\begin{array}{l}\text { Chlorurus perspicillatus } \\
\text { spectacled parrotfish }\end{array}$ & $0.14(0.18)$ & $0.01(0.04)$ & 15 & +1162 & Herbivore \\
\hline $\begin{array}{l}\text { Carcharhinus galapagensis } \\
\text { Galapagos shark }\end{array}$ & $0.13(0.01)$ & no & nd & + & Apex predator \\
\hline $\begin{array}{l}\text { Triaenodon obesus } \\
\text { whitetip reef shark }\end{array}$ & $0.11(0.01)$ & $<0.01(0.02)$ & 81 & +4883 & Apex predator \\
\hline $\begin{array}{l}\text { Carcharhinus amblyrhynchos } \\
\text { gray reef shark }\end{array}$ & $0.09(0.01)$ & no & nd & + & Apex predator \\
\hline $\begin{array}{l}\text { Melichthys niger } \\
\text { black triggerfish }\end{array}$ & $0.05(0.18)$ & $0.10(0.28)$ & 1 & -51 & $\begin{array}{l}\text { Lower-level } \\
\text { carnivore }\end{array}$ \\
\hline $\begin{array}{l}\text { Caranx melampygus } \\
\text { blue trevally }\end{array}$ & $0.05(0.04)$ & $<0.01(0.02)$ & 64 & +924 & Apex predator \\
\hline $\begin{array}{l}\text { Acanthurus leucopareius } \\
\text { whitebar surgeonfish }\end{array}$ & $0.05(2.29)$ & $0.04(0.12)$ & 4 & +19 & Herbivore \\
\hline $\begin{array}{l}\text { Chlorurus sordidus } \\
\text { bullethead parrotfish }\end{array}$ & $0.05(0.42)$ & $0.02(0.04)$ & 52 & +142 & Herbivore \\
\hline $\begin{array}{l}\text { Bodianus bilunulatus } \\
\text { Hawaiian hogfish }\end{array}$ & $0.04(0.06)$ & $<0.01(0.01)$ & 141 & +818 & $\begin{array}{l}\text { Lower-level } \\
\text { carnivore }\end{array}$ \\
\hline $\begin{array}{l}\text { Chromis ovalis } \\
\text { oval chromis }\end{array}$ & $0.04(2.56)$ & $<0.01(0.02)$ & 33 & +1439 & $\begin{array}{l}\text { Lower-level } \\
\text { carnivore }\end{array}$ \\
\hline $\begin{array}{l}\text { Naso unicornis } \\
\text { bluespine unicornfish }\end{array}$ & $0.04(0.11)$ & $0.03(0.17)$ & 7 & +32 & Herbivore \\
\hline $\begin{array}{l}\text { Scarus dubius } \\
\text { regal parrotfish }\end{array}$ & $0.03(0.74)$ & $<0.01(<0.01)$ & 143 & +37984 & Herbivore \\
\hline $\begin{array}{l}\text { Thalassoma ballieui } \\
\text { blacktail wrasse }\end{array}$ & $0.03(0.17)$ & $<0.01(<0.01)$ & 138 & +1279 & $\begin{array}{l}\text { Lower-level } \\
\text { carnivore }\end{array}$ \\
\hline $\begin{array}{l}\text { Aprion virescens } \\
\text { gray snapper }\end{array}$ & $0.02(0.04)$ & $<0.01(<0.01)$ & 130 & +1686 & Apex predator \\
\hline $\begin{array}{l}\text { Mulloidichthys vanicolensis } \\
\text { yellowfin goatfish }\end{array}$ & $0.02(0.47)$ & $<0.01(0.04)$ & 36 & +145 & $\begin{array}{l}\text { Lower-level } \\
\text { carnivore }\end{array}$ \\
\hline
\end{tabular}

Giant trevally Caranx ignobilis comprised $71 \%$ of apex predator biomass (equivalent to about $39 \%$ of total fish biomass) in the NWHI but only 1 individual was observed on 155 transects in the MHI. Several reef sharks (Triaenodon obesus, Carcharhinus amblyrhynchos, C. galapagensis) together contributed another $23 \%$ and $13 \%$ to apex predator and total fish biomass, respectively, in the NWHI while only 1 Triaenodon obesus, and no other sharks, were observed on transects in the MHI.

Chubs of 2 species (Kyphosus bigibbus and $K$. vaigiensis) represented a large minority (29\%) of herbivore biomass in the NWHI but only $3.7 \%$ of the herbivore biomass in the MHI. The endemic spectacled parrotfish Chlorurus perspicillatus was the second largest $(20 \%)$ contributor to herbivore biomass in the NWHI, but in the MHI it accounted for only $3 \%$ of the biomass in this guild. Four surgeonfishes (goldring surgeonfish Ctenochaetus strigosus; brown surgeonfish Acanthurus nigrofuscus; whitebar surgeonfish Acanthurus leucopareius) and orangespine unicornfish Naso lituratus together accounted for $46 \%$ of the total herbivorous fish biomass and $25 \%$ of the total fish biomass in the MHI. In the NWHI, these 4 species comprised less than $5 \%$ of total fish biomass.

The zooplanktivorous black triggerfish Melichthys niger was the largest single-species contributor of biomass in the MHI, accounting for nearly $16 \%$ of the total biomass and $37 \%$ of non-apex carnivore biomass. This species accounted for $12 \%$ of non-apex carnivore biomass and only $2 \%$ overall in the NWHI. Fishermen in the MHI do not typically target black triggerfish (Friedlander \& Parrish 1997), and their numerical abundance and biomass are both higher in the MHI compared to the NWHI.

Comparisons of length-frequency distributions of apex predators were made difficult by the lack of 
substantial numbers of this feeding guild in the MHI. Only 2 giant trevally Caranx ignobilis and 14 bluefin trevally C. melamypgus were encountered over 155 transects at 52 stations in the MHI. The lengthfrequency distributions of bluefin trevally were significantly different (Kolmogorov-Smirnov $D_{\max }=0.693$, $\mathrm{p}<0.001$ ) between the NWHI (mean length $=53 \mathrm{~cm}$ ) and the MHI (mean length $=32 \mathrm{~cm}$ ) (Fig. 5A). The distribution in the NWHI was right skewed with $26 \%$ in the $70-75 \%$ size class, whereas in the MHI, the frequency distribution was left skewed with $71 \%$ occurring in the $20-30 \mathrm{~cm}$ size class.

Herbivore biomass in the NWHI was dominated by chubs, spectacled parrotfish, whitebar surgeonfish, and bullethead parrotfish Chlorurus sordidus. Of these species, the 2 parrotfishes are important target species for spear, trap, and set-net fisheries in the MHI. Only 29 spectacled parrotfish $($ mean $=17 \mathrm{~cm}$ ) were observed in the MHI compared to 600 in the NWHI (mean = $31 \mathrm{~cm}$ ). There was a significant difference in these 2 length-frequency distributions $\left(D_{\max }=0.451, \mathrm{p}<\right.$ 0.001 ), with $38 \%$ of the spectacled parrotfish in the MHI less than $5 \mathrm{~cm}$ TL. Bullethead parrotfish showed a bimodal distribution in the NWHI with modes at 10 to 15 and 25 to $30 \mathrm{~cm}$, while the major mode in the MHI was 15 to $20 \mathrm{~cm}$ (Fig. 5B). Despite the similarity in means (NWHI and $\mathrm{MHI}=17 \mathrm{~cm}$ ) there was a significant difference in the central tendency between these 2 distributions $\left(D_{\max }=0.194, \mathrm{p}<0.001\right)$. Nearly $13 \%$ of the bullethead parrotfish in the NWHI were greater than $30 \mathrm{~cm}$ TL while $<1 \%$ in the MHI achieved this size.

The Hawaiian hogfish Bodianus bilunulatus is an endemic lower-level carnivore that is targeted by both spear and line fishermen in the MHI. The lengthfrequency distributions of this species were significantly different $\left(D_{\max }=0.358, \mathrm{p}<0.001\right)$ with the NWHI (mean $=29 \mathrm{~cm}$ ) having modes at 15 to $20 \mathrm{~cm}$ and 35 to $40 \mathrm{~cm}$ and the $\mathrm{MHI}$ having a single mode at 15 to $20 \mathrm{~cm}$ (mean $=20 \mathrm{~cm}$; Fig. 5C). Over $32 \%$ of the Hawaiian hogfish in the NWHI were greater than $35 \mathrm{~cm}$ TL while only $4 \%$ reached this size in the MHI.

\section{DISCUSSION}

Grand mean fish standing stock biomass in the NWHI was more than $260 \%$ greater compared to the MHI. These high biomass levels may reflect the greater secondary productivity potential of Hawaiian reefs when unfished. Differences in fish biomass between the MHI and NWHI represent both nearextirpation of apex predators and heavy exploitation of other, primarily carnivorous, lower-trophic level fishes, on shallow reefs of the MHI.
'Space-for-time' substitution has been used in many instances as an alternative to long-term studies to assess the impact of human-induced changes where pre-impact records are sparse or non-existent (Pickett 1989). In this case, we can infer the impacts of fishing by examining the differences in fish assemblages between the NWHI, a remote, lightly fished ecosystem, and MHI, an urbanized and heavily fished ecosystem. Although habitats differ between the NWHI and MHI, greater nutrient input and the presence of estuaries in the windward, vegetated $\mathrm{MHI}$ should result in a more, not less, productive ecosystem compared to the low islands and atolls of the NWHI. Expectations based on environmental differences thus reinforce rather than contradict our observations. Our observations of higher
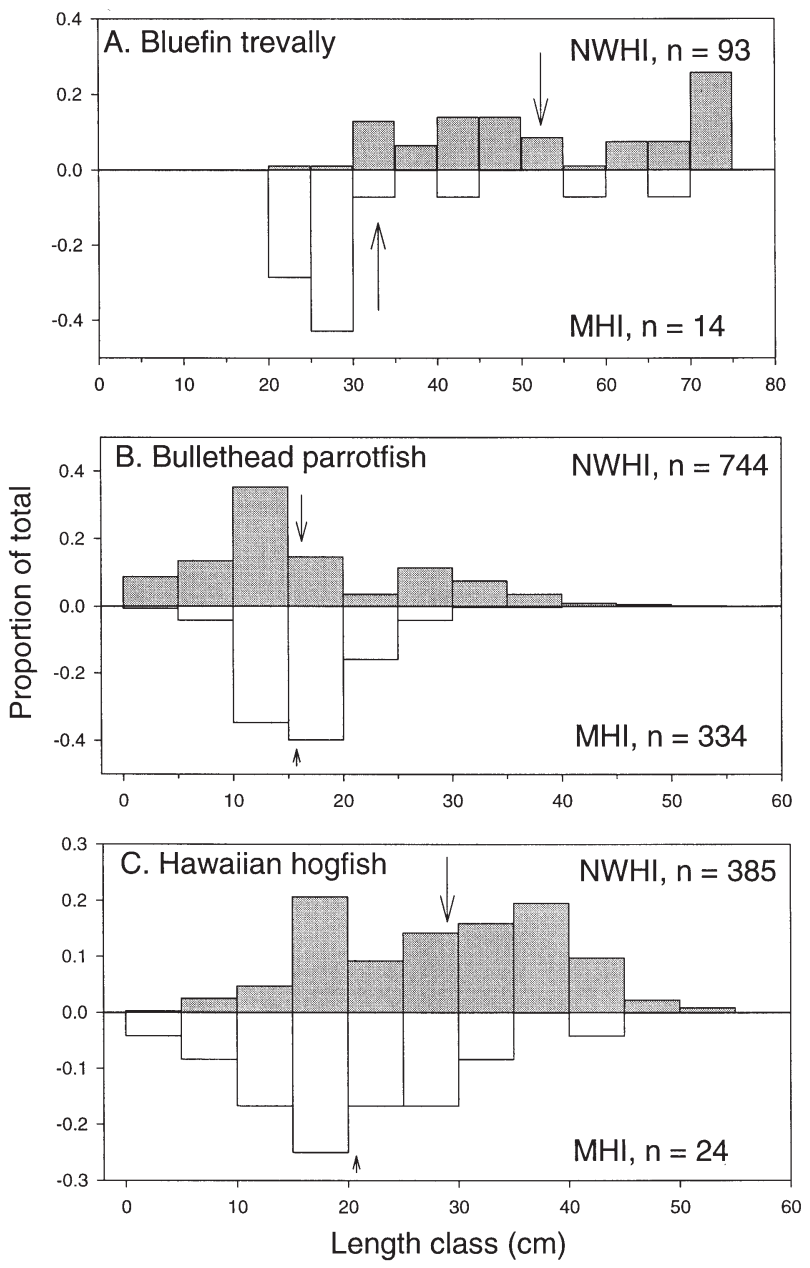

Fig. 5. Comparison of length-frequency distributions of representative species for each consumer guild in the northwestern Hawaiian islands (NWHI, solid bars) and main Hawaiian islands (MHI, open bars). Arrows denote location of the mean length of each distribution. (A) apex predators (bluefin trevally Caranx melampygus); (B) herbivores (bullethead parrotfish Chlorurus sordidus); (C) lower-level carnivores (Hawaiian hogfish Bodianus bilunulatus) 
fish standing stocks at less exploited sites (such as uninhabited Kahoolawe and no-take areas) within the MHI further reinforce our conclusions that these MHINWHI differences are caused by fishing.

Prior studies in both the NWHI and MHI corroborate our estimates of fish standing stock biomass at both areas. Grigg (1994) observed reef fish standing stock of $0.68 \mathrm{t} \mathrm{ha}^{-1}$ in fished areas in the MHI and $1.1 \mathrm{t} \mathrm{ha}^{-1}$ in areas with complete or partial protection from fishing. These values are comparable to other studies in the MHI: Kaneohe Bay, Oahu (0.9 t ha ${ }^{-1}$, Brock et al. 1979) and Hanalei Bay, Kauai (0.76 t ha ${ }^{-1}$, Friedlander \& Parrish 1997). In our present study, standing stock of herbivores and lower-level carnivores in the NWHI was $1.31 \mathrm{t} \mathrm{ha}^{-1}$. This 30 to $50 \%$ lower biomass of herbivores and lowerlevel carnivores in fished areas in the MHI compared to the NWHI illustrates the effects that intensive fishing also has had on lower trophic levels and hence the entire reef fish assemblage in the MHI. A consistent pattern over time of greater than $1 \mathrm{t} \mathrm{ha}^{-1}$ of herbivores and lower-level carnivores per year was observed at French Frigate Shoals and Midway Atoll in the NWHI over $7 \mathrm{yr}$ between 1992 and 2000 (DeMartini et al. unpubl.).

By comparison, average fish biomass in coastal southern California kelp Macrocystis pyrifera beds was estimated during the late 1970s and 1980s (after fishing down of apex predators and other large carnivorous fishes had already occurred) as ranging from about 0.2 to $0.6 \mathrm{t} \mathrm{ha}^{-1}$ (Larson \& DeMartini 1984, DeMartini \& Roberts 1990, DeMartini et al. 1996). Fish standing stock from various coral reef habitats on the Great Barrier Reef range from 0.9 to $2.4 \mathrm{t} \mathrm{ha}^{-1}$ (Williams \& Hatcher 1983) while locations from New Caledonia vary from 1.6 to $3.4 \mathrm{t} \mathrm{ha}^{-1}$ depending on the level of exploitation (Letourneur et al. 2000). The values observed in our study are consistent with those reported from other lightly exploited coral reefs in the Pacific and show the high secondary production potential of unfished coral reefs particularly in comparison to temperate reef ecosystems.

Detrended Correspondence Analysis of fish biomass with apex predators removed still shows distinct assemblages between the NWHI and MHI. Although latitudinal changes in assemblage structure are probable, fishing down of apex predators and lower trophic levels has likely had a major impact on the fish assemblage structure in the MHI. Heavy human cropping of lower-level carnivores as well as extirpation of apex predators may possibly be less disruptive than apex predator extirpation alone. It is feasible that the overfishing of apex predators only in the NWHI would more likely lead to ecosystem-wide impacts resulting from prey release and indirect effects on habitat than has been the case in the MHI, where humans have cropped the lower trophic levels as well.
Shallow-water snapper and groupers are typically important components of most coral reef ecosystems (Polovina \& Ralston 1987). Unlike most coral reef ecosystems around the world, there are very few native shallow-water snappers and groupers in Hawaii. Owing to the unique trophic dynamics on Hawaiian coral reefs, jacks and sharks, when present, account for most of the predator biomass and likely top-down control of these coral reef fish assemblages. Sudekum et al. (1991) estimate that giant trevally and bluefin trevally consume more than 30000 metric tons of fish and invertebrates per year at French Frigate Shoals (ca. $500 \mathrm{~km}^{2}$ of reef area to a depth of $20 \mathrm{~m}$ ) in the NWHI. These values exceed the estimated consumption by the 3 dominant shark species at this same location (DeCrosta et al. 1984) by a factor of 40 (Sudekum et al. 1991). Giant trevally consume diurnal reef fish but also eat nocturnal prey including eels, lobster, and octopus while bluefin trevally appear more dependent on diurnally active, shallow-water reef fishes including wrasses, goatfishes, damselfishes, parrotfishes, and filefishes (Sudekum et al. 1991). The abundance of these and other large jacks must certainly have a large top-down influence on the entire reef fish assemblage throughout the NWHI.

One of the few large benthic predators found on Hawaiian coral reefs is the Hawaiian grouper Epinephelus quernus. This species is rare at scuba depths in the MHI but was frequently observed on the forereef at Kure and Midway Atolls. It was very curious towards divers and as a result is probably highly susceptible to fishing pressure. Its restricted shallowwater range, curious nature, and status as an endemic species should all be taken into consideration in managing this species.

A number of species such as the spectacled parrotfish, Hawaiian hogfish, and bigeye emperor Monotaxis grandoculis are quite abundant and attain large size in the NWHI. These species are heavily exploited for subsistence and recreational use in the MHI, and their reduced number and size is likely the result of overfishing. Large, highly prized species, such as parrotfish, show a conditioned aversion to divers and are often observed with spear wounds in the MHI suggesting intensive pressure by spearfishermen in these areas.

As a result of intensive fishing pressure in the MHI, these coral reefs are stressed and do not contain the full complement of species and interrelationships that would prevail in the absence of humans. In addition to food fish, most of the marine ornamental fish and invertebrates originating from US waters are collected in Hawaii, which is known for its high quality animals and rare endemics of high value (Friedlander 2001, Tissot \& Hallacher in press). There are no regulations 
limiting the size, number, or collecting season for most species, and the number of collectors has increased dramatically in recent years (Tissot \& Hallacher in press). Owing to the harvest of preferred food fish and desirable aquarium fish species, the only abundant fishes remaining on MHI coral reefs are often drab, small-bodied species of no ornamental and little food value, such as black triggerfish, brown surgeonfish, and orangespine unicornfish.

Fish biomass on intensely fished reefs is often dominated by herbivores, while lightly fished reefs have a higher proportion of piscivores and invertebrate feeders (Jennings \& Polunin 1996). Fishing down food webs by removing higher trophic levels can result in relaxation of top-down control that can lead to a phase transition to ecosystems dominated by lower trophic guilds (Carpenter et al. 1985, Pauly et al. 1998, Pinnegar et al. 2000). These top carnivores have specialized niches that when depleted can lead to a cascade of species extinctions (Christensen \& Pauly 1997). Pitcher (2001) terms this 'Odum's ratchet' (see Gibbons \& Odum 1993) because once these species (or genotypes) become extinct it is difficult to restore the ecosystem to its former state. The removal of these species can also have a destabilizing effect on ecosystems by making them more vulnerable to natural and anthropogenic disturbances (Jackson et al. 2001).

The poor performance of conventional fisheries management worldwide has led to increased interest in marine reserves as a solution to the problems of overfishing (Murray et al. 1999). Successful enhancement of localized fish stocks by establishing closed areas and marine reserves is well documented (Pauly 1979, Pitcher \& Hart 1982, Gulland 1988, Russ 1991, Roberts \& Polunin 1991, 1993, Roberts 1995, Bohnsack 1996, 1998). Marine reserves create an off-limits population, which in theory can provide greater stability in the dynamics of the exploited population and can be incorporated into a management system as a buffer against uncertainty (Sladek Nowlis \& Friedlander in press).

A variety of marine areas in the MHI have some type of protected status. These include Marine Life Conservation Districts (MLCDs), Fisheries Management Areas (FMAs), a Marine Laboratory Refuge, Natural Area Reserves (NARs), Fisheries Replenishment Areas (FRAs), National Wildlife Refuges, Island Reserves (Kahoolawe Island Reserve) and the Hawaiian Islands Humpback Whale Sanctuary (Clark \& Gulko 1999). However, many of these reserves are either too small, lack suitable habitats, or are not fully protected from fishing and therefore do not function effectively as refuges (Friedlander 2001, Friedlander et al. unpubl.). Fully protected no-take reserves in the MHI have higher standing stocks of reef fishes compared to areas where fishing is permitted or areas with partial protec- tion from fishing (Grigg 1994, Friedlander 2001), yet these reserves account for less than $0.3 \%$ of the area surrounding the MHI (Gulko et al. 2000). The largest well-protected area in the MHI, Kahoolawe, had the highest biomass observed in this island group and had similar biomass to Kure Atoll, the location with the lowest biomass in the NWHI. Kure is the only location in the NWHI other than Midway Atoll that receives some fishing pressure from the recreational (catch and release) sport fishery based at Midway (R. Shallenberger, USFWS, pers. comm.). Larger refuges may be necessary for highly vagile species such as jacks and sharks (DeMartini 1993), and the overall percentage of no-take reserves should increase dramatically so that reef fish populations can recover to former levels.

Predator-dominated coral reef ecosystems may well be the natural state, but they contain the species that are most susceptible to, and so rapidly removed by human activities, thus making the natural state difficult to observe in most cases. The NWHI are an exception because the limited fishing activities that have occurred there have resulted in minimal anthropogenic impacts. These reefs are among the few remaining large-scale, intact, predator-dominated reef ecosystems left in the world and offer a chance to examine what could occur if larger, more effective, notake marine protected areas were implemented in the MHI. The value of these areas extends beyond the intrinsic; they also have the potential to enhance fishing and hedge against fisheries collapses by potentially providing sources of recruits and propagules. The NWHI is one of the few places left in the world that is sufficiently pristine to study how unaltered ecosystems are structured, how such ecosystems function, and how they can be most effectively preserved. The differences in fish assemblage structure detailed in this study are evidence of the high level of exploitation in the MHI and the pressing need for ecosystem-level management of reef systems in the MHI as well as NWHI.

Acknowledgements. Funding for this study was provided by NOAA/NOS Hawaii Coral Reef Initiative to the Hawaii Coral Reef Assessment and Monitoring Program and the Northwestern Hawaiian Islands Reef Assessment and Monitoring Program. Ray Boland, Eric Brown, Steve Cotton, Brent Carman, Randall Kosaki, Jason Leonard, Richard Wass, Lisa Wedding, and William Walsh all participated in various portions of data collection. Jean Kenyon, Steve Cotton, Rusty Brainard, and Jim Maragos reviewed earlier versions of this manuscript and provided valuable comments.

\section{LITERATURE CITED}

Bohnsack JA (1998) Application of marine reserves to reef fisheries management. Aust J Ecol 23:298-304 
Bohnsack JA (1996) Maintenence and recovery of reef fishery productivity. In: Polunin NVC, Roberts CM (eds) Reef fisheries. Chapman and Hall, London, p 283-313

Brock RE (1982) A critique of the visual census method for assessing coral reef fish populations. Bull Mar Sci 32:269-276

Brock RE, Lewis C, Wass RC (1979) Stability and structure of a fish community on a coral patch reef in Hawaii. Mar Biol 54:281-292

Brock VE (1954) A preliminary report on a method of estimating reef fish populations. J Wildl Manage 18:297-308

Carpenter, SR, Kitchell JF, Hodgson JR (1985) Cascading trophic interactions and lake productivity. BioScience 35: 634-639

Christensen V, Pauly D (1997) Changes in models of aquatic ecosystems approaching carrying capacity. Ecol Appl 8:104-109

Clark AM, Gulko D (1999) Hawaii's state of the reefs report, 1998. Division of Aquatic Resources, Department of Land and Natural Resources, State of Hawaii, Honolulu, Hawaii

Dayton P (1998) Reversal of the burden of proof in fisheries management. Science 279:821-822

Dayton PK, Tegner MJ, Edwards PB, Riser KL (1998) Sliding baselines, ghosts and reduced expectations in kelp forest communities. Ecol Appl 8:309-322

DeCrosta MA, Talyor LR Jr, Parrish JD (1984) Age determination, growth, and energetics of three species of carcharhinid sharks in Hawaii. In: Grigg RW, Tanoue KY (eds) Proc 2nd Symp on resource investigations in the northwestern Hawaiian islands, Vol 2. UNIHI-SEAGRANT-MR-84-01, University of Hawaii Sea Grant College Program, Honolulu, p 75-95

DeMartini EE (1993) Modeling the potential of fishery reserves for managing Pacific coral reef fishes. Fish Bull 91:414-427

DeMartini EE, Roberts DA (1990) Effects of giant kelp (Macrocystis) on the density and abundance of fishes in a cobble-bottom kelp forest. Bull Mar Sci 46:287-300

DeMartini EE, Parrish FA, Parrish JD (1996) Interdecadal change in reef fish populations at French Frigate Shoals and Midway Atoll, northwestern Hawaiian islands: statistical power in retrospect. Bull Mar Sci 58:804-825

Friedlander AM (2001) Essential fish habitat and the effective design of marine reserves: applications for marine ornamental fishes. Aquarium Sci Conserv 3:135-150

Friedlander AM, Parrish JD (1997) Fisheries harvest and standing stock in a Hawaiian Bay. Fish Res 32:33-50

Friedlander AM, Ziemann DA (in press) Impact of hatchery releases on the recreational fishery for Pacific threadfin in Hawaii. Fish Bull

Friedlander A, Poepoe K, Poepoe K, Helm K, Bartram P, Maragos J, Abbott I (in press) Application of Hawaiian traditions to community-based fishery management. Proc 9th Int Coral Reef Symp, Bali

Gauch HG Jr (1982) Multivariate analysis in community ecology. Cambridge University Press, Cambridge

Gibbons W, Odum EP (1993) Keeping all the pieces: perspectives on natural history and the environment. Smithsonian Institution Press, Washington, DC

Greenfield DW, Johnson RK (1990) Heterogeneity in habitat choice in cardinalfish community structure. Copeia 4: $1107-1114$

Grigg RW (1994) Effects of sewage discharge, fishing pressure and habitat complexity on coral ecosystems and reef fishes in Hawaii. Mar Ecol Prog Ser 103:25-34

Gulko D, Maragos J, Friedlander A, Hunter C, Brainard R (2000) Status of coral reef in the Hawaiian archipelago. In:
Wilkinson C (ed) Status of coral reefs of the world. Australian Institute of Marine Science, Cape Ferguson, Queensland, p 219-238

Gulland JA (1988) Fish population dynamics: the implications for management. John Wiley and Sons, Chichester

Hobson ES (1984) The structure of reef fish communities in the Hawaiian Archipelago. In: Grigg R, Tanoue K (eds) Proc 2nd Symp on Resource Investigations in the Northwestern Hawaiian Islands, Vol 1. UNIHI-SEAGRANTMR-84-01, University of Hawaii Sea Grant College Program, Honolulu, p 101-122

Jackson JBC (1997) Reefs since Columbus. Coral Reefs 16:S23

Jackson JBC, Kirby MX, Berger WH, Bjorndal KA and 15 others (2001) Historical overfishing and the recent collapse of coastal ecosystems. Science 293:629-638

Jennings S, Kaiser MJ (1998) The effects of fishing on marine ecosystems. Adv Mar Biol 34:201-352

Jennings S, Polunin NVC (1996) Effects of fishing effort and catch rates upon the structure and biomass of Fijian reef fish communities. J Appl Ecol 33:400-412

Jennings S, Polunin NVC (1997) Impacts of predator depletion by fishing on the biomass and diversity of non-target reef fish communities. Coral Reefs 16:71-82

Juvik SP, Juvik JO (1998) Atlas of Hawaii, 3rd edn. University of Hawaii Press, Honolulu

Koslow JA, Hanley F, Wiclaud R (1988) Effects of fishing on reef fish communities at Pedro Bank and Port Royal Cays, Jamaica. Mar Ecol Prog Ser 43:201-212

Larson RJ, DeMartini EE (1984) Abundance and vertical distribution of fishes in a cobble-bottom kelp forest off San Onofre, California. Fish Bull 82:37-53

Letourneur Y, Kulbicki M, Labrosse P (2000) Fish stock assessment of the northern New Caledonian lagoons: 1 . Structure and stocks of coral reef fish communities. Aquat Living Resour 13:65-76

Lowe MK (1996) Protecting the future of small scale fisheries in an economy dominated by tourism and coastal development, based on the results of the main Hawaiian Islands marine resources investigation (MHI-MRI). In: Nagata S (ed) Ocean resources: development of marine tourism, fisheries, and coastal management in the Pacific Islands area. Proc 6th Pacific Islands Area Seminar. Tokai University, Honolulu, p 137-142

Martin PS (1984) Prehistoric overkill: the global model. In: Martin PS, Klein RG (eds) Quanternary extinctions: a prehistoric revolution. University of Arizona Press, Tucson, p 354-403

Murray SN, Ambrose RF, Bohnsack JA, Botsford LW and 15 others (1999) No-take reserve networks: protection for fishery populations and marine ecosystems. Fisheries 24(11):11-25

NRC (US National Research Council) (1995) Understanding marine biological diversity. National Academy Press, Washington, DC

Okamoto H, Kawamoto B (1980) Progress report on the nearshore fishery resource assessment of the Northwestern Hawaiian Islands, 1977-79. In: Grigg R, Tanoue K (eds) Proc 2nd Symp on Resource Investigations in the Northwestern Hawaiian Islands, Vol 1. UNIHI-SEAGRANT-MR-84-01, University of Hawaii Sea Grant College Program, Honolulu, p 71-80

Parrish JD, Callahan MW, Norris JE (1985) Fish trophic relationships that structure reef communities. Proc 5th Int Coral Reef Congr, Tahiti, 4:73-78

Pauly D (1979) Theory and management of tropical multispecies stocks: a review with emphasis on the South East Asian demersal fisheries. ICLARM Studies and Reviews 1, 
Manila, Philippines

Pauly D (1995) Anecdotes and the shifting baseline syndrome of fisheries. Trends Ecol Evol 10:430

Pauly D, Christensen V, Dalsgaaard J, Froese R, Torres F Jr (1998) Fishing down marine food webs. Science 279: 860-863

Pickett STA (1989) Space-for-time substitution as an alternative to long-term studies. In: Likens GE (ed) Long-term studies in ecology: approaches and alternatives. SpringerVerlag, New York, p 110-135

Pinnegar JK, Polunin NVC, Francour P, Badalamenti F and 7 others (2000) Trophic cascades in benthic marine ecosystems: lessons for fisheries and protected-area management. Environ Conserv 27:179-200

Pitcher TJ (2001) Rebuilding ecosystems as a new goal for fisheries management: reconstructing the past to salvage the future. Ecol Appl 11:601-617

Pitcher TJ, Hart PJB (1982) Fisheries ecology. AVI Publishing, Westport, CT

Polovina JJ, Ralston S (1987) Tropical snappers and groupers: biology and fisheries management. Westview Press, Boulder, $\mathrm{CO}$

Roberts CM (1995) Rapid build-up of fish biomass in a Caribbean marine reserve. Conserv Biol 9:815-826

Roberts CM, Polunin NVC (1991) Are marine reserves effective in management of reef fisheries? Rev Fish Biol Fish 1:65-91

Roberts CM, Polunin NVC (1993) Marine reserves: simple solutions to managing complex fisheries? Ambio 22:363-368

Russ GR (1991) Coral reef fisheries: effects and yields. In: Sale PF (ed) The ecology of fishes on coral reefs. Academic Press, San Diego, p 601-635

Editorial responsibility: Charles Birkeland (Contributing Editor), Honolulu, Hawaii, USA
Russ GR, Alcala AC (1996) Marine reserves-rates and patterns of recovery and decline of large predatory fish. Ecol Appl 6:947-961

Sheppard C (1995) The shifting baseline syndrome. Mar Poll Bull 30:766-767

Shomura R (1987) Hawaii's marine fishery resources: yesterday (1900) and today (1986). US Dept Comm, NOAA, NMFS, Southwest Fish Sci Cent Admin Rep H-87-21, Honolulu

Siegel S, Castellan NJ Jr (1988) Nonparametric statistics for behavioral sciences, 2nd edn. McGraw-Hill, New York

Sladek Nowles J, Friedlander AM (in press) Marine reserve design and function for fisheries management. In: Norse EA, Crowder LB (eds) Marine conservation biology: the science of maintaining the sea's biodiversity. Island Press, California

Smith MK (1993) An ecological perspective on inshore fisheries in the main Hawaiian Islands. Mar Fish Rev 55:31-46

Sudekum AE, Parrish JD, Radtke RL, Ralston S (1991) Life history and ecology of large jacks in undisturbed, shallow, oceanic communities. Fish Bull 89:493-513

Tissot BN, Hallacher LE (in press) The effects of aquarium collectors on coral reef fishes in Hawaii. Conserv Biol

USFWS (US Fish and Wildlife Service) (1998) 1996 National survey of fishing, hunting and wildlife-associated recreation. Dept Int, US Fish and Wildlife Service and Dept Comm, Bureau of the Census, Washington, DC

Ward P (1997) The call of distant mammoths: why the ice age mammals disappeared. Copernicus Press, New York

Williams DMB, Hatcher AI (1983) Structure of fish communities on outer slopes of inshore, mid-shelf and outer shelf reefs of the Great Barrier Reef. Mar Ecol Prog Ser 10: 239-250

Submitted: October 8, 2001; Accepted: December 28, 2001 Proofs received from author(s): March 13, 2002 